\title{
Thrips (Insecta, Thysanoptera) of Iran: a revised and updated checklist
}

\author{
Kambiz Minaei ${ }^{1}$ \\ I Department of Plant Protection, College of Agriculture, Shiraz University, Shiraz, Iran \\ Corresponding author:Kambiz Minaei (kminaei@shirazu.ac.ir)
}

Academic editor: L. Mound | Received 7 July 2013 | Accepted 15 August 2013 | Published 11 September 2013

Citation: Minaei K (2013) Thrips (Insecta, Thysanoptera) of Iran: a revised and updated checklist. ZooKeys 330: 53-74. doi: $10.3897 /$ zookeys.330.5939

\begin{abstract}
In Iran, as a result of recent changes in nomenclature 201 species and one species group of the insect Order Thysanoptera, are here listed in 70 genera and five families. In considering species listed previously from this country, the presence of 7 species is considered not confirmed, and 12 species are excluded from the Iranian list. Problems in the study of Iranian Thysanoptera are discussed briefly.
\end{abstract}

\section{Keywords}

Iran, list, species, Thysanoptera

\section{Introduction}

Iran forms a large part of the Iranian plateau, and covers an area of $1,623,779 \mathrm{~km}^{2}$. It is bordered in the north by the Caucasus Mountains, Middle Asian natural regions and the Caspian Sea (-27 m below sea level); in the west by the Anatolian and Mesopotamian regions; in the east by the eastern part of the Iranian plateau (Afghanistan and adjacent west Pakistan) and the Baluch-Sindian region; and finally in the south by the Persian Gulf and Oman Sea, which are connected by the latter to the Indian Ocean (Zehzad et al. 2002).

In Iran, the first record of thrips species was of three species, Frankliniella intonsa (Trybom), Thrips flavus Schrank and T. tabaci Lindeman, as pests of summer crops (Afshar 1938), and after that there were several scattered studies of this group in vari- 
ous parts of this country. Recently the extensive Iranian literature on these insects was summarised by Bhatti et al. (2009a), who listed 177 species in 62 genera. However that checklist needs further consideration for four reasons:

1. The checklist by Bhatti et al. (2009a) covers the literature until 2007 and since then several important works on Thysanoptera of Iran have been published, including a further 13 genera and 38 species recorded or described. Moreover, a few recent name changes have become available.

2. There are some misinterpretations of "Iranian Persian literature" in Bhatti et al. (2009a). Thus a few species have appeared in Iranian literature as potential pests or as exotic pests without any supporting data or records from Iran.

3. Bhatti et al. (2009a) did not employ the standard suprageneric classification of Thysanoptera, so the utility of the checklist for students is limited.

4. The restricted distribution of the journal in which the book (Bhatti et al. 2009a) was published limits its utility to entomologists in Iran as well as the world.

\section{Thrips studies in Iran: problems}

Relevant information about thrips species recorded from Iran is severely lacking. For example, until the end of 2007, 187 primary references had been published on Iranian Thysanoptera, but, of these, 123 (65\%) appeared only as "abstracts". Almost all of these consisted solely of species lists, without any further information being provided as to the number of collected specimens, their sex, or the habitats in which the species were collected. In one of these abstracts (Mortazaviha 1995) even the specific locality where the species were collected is not given, and for 15 thrips species collection details are restricted to the country "Iran". A further problem is the difficulty in tracing collections in which relevant voucher specimens were placed; and for many species there appear to be no extant voucher specimens. For example, Haplothrips minutus was recorded by Kheyrandish Koshkoei et al. (2000), but when asked for a loan of material Kheyrandish Koshkoei (personal communication, 2006) responded that he did not have access to any specimens of that species. Similarly, two papers (Mehrnejad and Panahi 2006; Kazemi and Mehrnejad 2011) concerning the biology and pest status of Liothrips austriacus (Karny) have been published from work carried out at the "Pistachio Research Institute" in Rafsenjan, Kerman Province, but no specimens of that species are available from that Institute at present (F. Kazemi, personal communication, 2013). Furthermore, in recent years Majid Mirab-balou has described or recorded several thrips species from Iran, but the specimens (including type specimens) have been deposited in China (Mirab-balou and Chen 2012a, b).

The third problem, related to the above, is imprecise reporting by Iranian authors. Several species have been reported from Iran despite the original specific identifications on which these reports are based remaining tentative. For example, the Iranian 
records for three Haplothrips species reported by Bagheri and Alavi (2007) are based on specimens identified by zur Strassen as "perhaps" those species (Minaei and Mound 2008). Similarly, three Aeolothrips species recorded by Fallahzadeh et al. (2011) were only tentatively identified to species by Bhatti (Minaei 2013a).

\section{A revised checklist of Thysanoptera from Iran}

The following checklist is organized following the standard taxonomic hierarchy, and is based on published literatures including Bhatti et al. (2009a). For each suprageneric category a brief description is provided based largely on the Iranian fauna. Higher level taxonomy in the checklist follows Mound (2011a). Nomenclature follows that used in a web-based world checklist (ThripsWiki 2013), which should also be referred to for full synonymies for the names listed here. The checklist includes references for all additions and changes in taxonomic status or changes in synonymy made since the publication of the previous checklist by Bhatti et al. (2009a), and the symbol + is used to indicate these changes.

\section{Suborder Terebrantia}

The Terebrantia comprises eight families (Mound 2011a) of which four (Aeolothripidae, Melanthripidae, Stenurothripidae, Thripidae) are represented in Iran. Terebrantia species are largely phytophagous, feeding in flowers and on leaves.

\section{Family Aeolothripidae}

The family includes 194 extant species in 23 genera (ThripsWiki 2013), mostly from the temperate areas of the northern and southern hemispheres. Adults and larvae of many species in this family appear to be facultative predators of other small arthropods, in that they feed on both floral tissues as well as on thrips and mites that live in flowers. However, some species are almost certainly solely phytophagous, a few being univoltine in flowers of particular plant species (Tyagi et al. 2008), whereas in the warmer parts of the world, a considerable number of species are obligate predators (Hoddle 2003).

In this family, the most species-rich genus, Aeolothrips was interpreted by Bhatti (1988) in a different way to other specialists, with Aeolothrips restricted to albicinctus Haliday. Bhatti's interpretation put all other species from the original genus into four further genera (Arabthrips Bhatti, Coleothrips Haliday, Fabothrips Bhatti, Podaeolella Priesner). In this paper, that interpretation is not accepted. Four genera including 23 species are recognized in this family in Iran. 


\section{Aeolothrips Haliday, 1836}

+ afghanus Jenser, 1984

albicinctus Haliday, 1836

collaris Priesner, 1919

+ cursor Priesner, 1939

deserticola Priesner, 1929

+ eremicola Priesner, 1938

fasciatus (Linnaeus, 1758)

gloriosus Bagnall, 1914

heinzi zur Strassen, 1990

intermedius Bagnall, 1934

+ modestus zur Strassen, 1966

mongolicus Pelikan, 1985

+ montivagus Priesner, 1948

tenuicornis Bagnall, 1926

versicolor Uzel, 1895

+ wittmeri Priesner, 1935

+ zurstrasseni Minaei

\section{Indothrips Bhatti, 1967}

bhushani Bhatti, 1967

\section{Orothrips Moulton, 1907}

priesneri (Titschack, 1958)

\section{Rhipidothrips Uzel, 1895}

brunneus Williams, 1913

flavus Tunç, 1991

gratiosus Uzel, 1895

unicolor zur Strassen, 1965 male described by Minaei et al. (2013)

added by Mirab-balou and Chen (2012c)

added by Zolfaghari et al. (2012); male de scribed by Alavi et al. (2013)

added by Minaei (2013a)

added by Mirab-balou and Chen (2012c)

added by Alavi et al. (2012)

described by Minaei (2013a)

\section{Family Melanthripidae}

Melanthripids were considered to be members of the Aeolothripidae until recently. The family now includes 66 extant species in four genera: Ankothrips (13 species), Cranothrips (11 species), Dorythrips (6 species) and Melanthrips (35 species). All species in the family are flower-feeding but each genus exhibits a remarkable discontinuity in geographical distribution: Cranothrips and Dorythrips are known only from the Southern Hemisphere, whereas Ankothrips and Melanthrips are mainly from the Northern Hemisphere but each with one or two species from South Africa (Pereyra and Mound 2009, Hoddle et al. 2013). In Iran, seven species in two genera have been recorded. 
Ankothrips Crawford, 1909

+ zayandicus Minaei, Haftbaradarn \& Mound, 2012 described by Minaei et al.

(2012)

Melanthrips Haliday, 1836

fuscus (Sulzer, 1776)

+ hei Mirab-balou \& Chen, 2012 described by Mirab-balou and Chen (2012a)

knechteli Priesner, 1936

pallidior Priesner, 1919

rivnayi Priesner, 1936

separandus Priesner, 1936

\section{Family Stenurothripidae}

The extant species in this group were placed in the family Adiheterothripidae (Bhatti 1986), but this is now considered a synonym of Stenurothripidae (Bhatti 2006). The three extant genera of this family occur in California and in the Mediterranean region through to India (Mound and Marullo 1999). The species in this family apparently all breed in flowers, and they probably have a high degree of host specificity. All four species of Holarthrothrips breed in the male flowers of date palms and its relatives (Mound et al. 2013b). Only one species is recorded in Iran.

\section{Holarthrothrips Bagnall, 1927}

josephi Bhatti, 1986

\section{Family Thripidae}

Thripids include 2020 species in 284 genera worldwide (ThripsWiki 2013). Most of them are phytophagous on higher plants, with a few species on ferns (Mound 2002), and a few are obligate predators (Mound 2011b). However, some polyphagous pest thrips such as Frankliniella occidentalis and Thrips tabaci can behave as facultative predators (Wilson et al. 1996). One genus in Brazil comprises species that are ectoparasitic on Hemiptera (Cavalleri et al. 2010). Four subfamilies within the Thripidae are currently recognized worldwide, and each of these is represented in Iran.

\section{Thripidae-Dendrothripinae}

More than 90 species, in 11 genera, are recognized worldwide in this subfamily (ThripsWiki 2013). All of the species live on leaves. Five species in two genera have been recorded in Iran. 


\section{Dendrothrips Uzel, 1895}

degeeri Uzel, 1895

karnyi Priesner, 1921

phyllireae (Bagnall, 1927)

saltator Uzel, 1895

\section{Pseudodendrothrips Schmutz, 1913}

mori (Niwa, 1908)

\section{Thripidae-Panchaetothripinae}

Wilson (1975) provided an account of the members of this subfamily that is now considered to include 136 species in 38 genera. The species in this subfamily are all leaf feeding usually associated with older, senescing leaves (Mound et al. 2013b). Seven species in six genera have been found in Iran so far.

\section{Caliothrips Daniel, 1904}

impurus (Priesner, 1928)

+ quadrifasciatus

the species is recorded as Caliothrips graminicola Bagnall \& Cameron, 1932 in Iranian literature

\section{Heliothrips Haliday, 1836}

haemorrhoidalis (Bouche, 1833)

\section{Parthenothrips Uzel, 1895}

dracaenae (Heeger, 1854)

Retithrips Marchal, 1910

syriacus (Mayet, 1890)

Rhipiphorothrips Morgan, 1913

cruentatus Hood, 1919

\section{Selenothrips Karny, 1911}

+ rubrocinctus (Giard, 1901)

added by Mirab-balou and Chen (2012d)

\section{Thripidae-Sericothripinae}

This group is treated as a subfamily of Thripidae to include three genera: Hydatothrips Karny, Neohydatothrips John, Sericothrips Haliday (ThripsWiki 2013). This subfamily 
includes 148 species worldwide, and these are usually found in association with flowers but with some species breeding on leaves (Mound and Tree 2009). Bhatti (2006) proposed Papiliothrips as a new genus and transferred Neohydatothrips gracilicornis and two species of Sericothrips to the genus, but this is not accepted here. Two species in one genus are reported in Iran so far.

Neobydatothrips John, 1929

gracilicornis (Williams, 1916)

tadzhicus (Pelikan, 1964)

\section{Thripidae-Thripinae}

This is the largest group of Thripidae with 1644 species in 232 genera (ThripsWiki 2013). The species exhibit a wide range of biologies, and most of the species of thrips regarded as pests are included in this subfamily (Mound 1997). Bhatti et al. (2009a) synonymized Chirothrips aculeatus Bagnall with Chirothrips pedestris (Karny). However, this was not accepted by other researchers (Minaei and Mound 2010a). Moreover, in contrast to zur Strassen (2003) and Bhatti et al. (2009a), three Chirothrips species recorded in Iran (africanus Priesner, manicatus (Haliday), pallidicornis Priesner), together with ammophilae Bagnall, were placed in a manicatus species group by Minaei and Mound (2010a) due to the difficulty in separating them from each other by morphological characters, and this approach is accepted here. Two species listed under the genus Thrips, T. iranicus Yakhontov and T. pistaciae Yakhontov, are not recognizable at present due to the poor descriptions (see Bhatti et al. 2009a). In addition, T. fraudulentus (Priesner) is very similar to T. atratus Haliday. Laurence Mound (personal communication 2010) examined the holotype of fraudulentus in the Forschungsinstitut Senckenberg, Frankfurt, and although there are differences in the lengths of the antennae the recognition of fraudulentus as a distinct species remains doubtful. In Iran, 110 species and one species-group in 35 genera in this subfamily are recognized.

Agalmothrips Priesner, 1965

parviceps (Priesner, 1965)

Anaphothrips Uzel, 1895

+ obscurus (Müller, 1776)

male described by Mirab-balou and Chen (2010)

sudanensis Trybom, 1911

\section{Aptinothrips Haliday, 1836}

elegans Priesner, 1924

rufus (Haliday, 1836)

stylifer Trybom, 1894 


\section{Arorathrips Bhatti, 1990}

+ mexicanus (Crawford DL, 1909) added by Minaei and Alichi (in press)

Bregmatothrips Hood, 1912

bournieri Pelikan, 1988

\section{Chirothrips Haliday, 1836}

aculeatus (Bagnall, 1927)

+ atricorpus (Girault, 1927)

kurdistanus zur Strassen, 1967

+ manicatus species-group

+ maximi Ananthakrishnan, 1957

+ meridionalis Bagnall, 1927

molestus Priesner, 1926

\section{Collembolothrips Priesner, 1935}

mediterraneus Priesner, 1935

\section{Drepanothrips Uzel, 1895}

reuteri Uzel, 1895

\section{Eremiothrips Priesner, 1950}

antilope (Priesner, 1923)

arya (zur Strassen, 1975)

+ bhattii Minaei, 2012

described by Minaei (2012)

dubius (Priesner, 1933)

stat. rev. by Minaei and Mound (2010a)

defined by Minaei and Mound (2010a)

added by Mirab-balou et al. (2013)

stat. rev. by Minaei and Mound (2010a)

efflatouni (Priesner, 1965)

farsi Bhatti \& Telmadarraiy, 2003

shirabudinensis (Yakhontov, 1929)

+ similis Bhatti, 1988

added by Ramezani et al. (2009)

taghizadehi (zur Strassen, 1975)

tamaricis (zur Strassen, 1975)

varius (Bhatti, 1967)

+ zurstrasseni Bhatti, Bagheri \& Ramezani, 2009 described by Bhatti et al. (2009b)

Euphysothrips Bagnall, 1926

minozzii Bagnall, 1926

\section{Exothrips Priesner, 1939}

redox Bhatti, 1975

Ficothrips Minaei, 2012

+ moundi Minaei, 2012

described by Minaei (2012a) 
Frankliniella Karny, 1910

intonsa (Trybom, 1895)

occidentalis (Pergande, 1895)

pallida (Uzel, 1895)

schultzei (Trybom, 1910)

tenuicornis (Uzel, 1895)

Kakothrips Williams, 1914

+ dentatus Knechtel, 1939

pisivorus (Westwood, 1880)

priesneri Pelikan, 1965

\section{Limothrips Haliday, 1836}

angulicornis Jablonowski, 1894

+ cerealium (Haliday, 1836)

denticornis (Haliday, 1836)

schmutzi Priesner, 1919

transcaucasicus Savenko, 1944

\section{Megalurothrips Bagnall, 1915}

+ distalis (Karny, 1913)

\section{Microcephalothrips Bagnall, 1926}

abdominalis (Crawford DL, 1910)

\section{Mycterothrips Trybom, 1910}

consociatus (Targioni-Tozzetti, 1887)

+ hamedaniensis Mirab-balou, Shi \& Chen, 2011 described by Mirab-balou et

latus (Bagnall, 1912)

al. (2011)

salicis (Reuter, 1879)

tschirkunae (Yakhontov, 1961)

+ weii Mirab-balou, Shi \& Chen, 2011 described by Mirab-balou et al. (2011)

\section{Odontothrips Amyot \& Serville, 1843}

confusus Priesner, 1926

loti (Haliday, 1852)

added by Mirab-balou and Chen (2011b)

meliloti Priesner, 1951

phlomidinus Priesner, 1954

\section{Oxythrips Uzel, 1895}

+ claripennis Priesner, 1940

halidayi Bagnall, 1924 added by Mirab-balou and Chen (2011a)

added by Mirab-balou et al. (2013) 
retamae (Priesner, 1934)

ulmifoliorum (Haliday, 1836)

wiltshirei Priesner, 1954

Parascolothrips Mound, 1967

priesneri Mound, 1967

Pezothrips Karny, 1907

bactrianus (Pelikan, 1968)

Psilothrips Hood, 1927

bimaculatus (Priesner, 1932)

Rubiothrips Schliephake, 1975

+ parisae Mirab-balou \& Chen, 2013 described by Mirab-balou and Chen (2013)

+ tongi Mirab-balou \& Chen, 2013 described by Mirab-balou and Chen (2013)

+ vitalbae (Bagnall, 1926)

vitis (Priesner, 1933)

Scirtothrips Shull, 1909

mangiferae Priesner, 1932

Scolothrips Hinds, 1902

latipennis Priesner, 1950

longicornis Priesner, 1926

rhagebianus Priesner, 1950

Sitothrips Priesner, 1931

arabicus Priesner, 1931

Sphaeropothrips Priesner, 1928

vittipennis (Bagnall, 1927)

Stenchaetothrips Bagnall, 1926

+ biformis (Bagnall, 1913) added by Mirab-balou and Chen (2013) 


\section{Tamaricothrips Priesner, 1964}

tamaricis (Bagnall, 1926)

\section{Tenothrips Bhatti, 1967}

discolor (Karny, 1907)

frici (Uzel, 1895)

latoides (Pelikan, 1968)

reichardti (Priesner, 1926)

\section{Thermothrips Pelikan, 1949}

+ mohelensis (Pelikan, 1949)

\section{Thrips Linnaeus, 1758}

alavii Mirab-balou, Tong \& Chen, 2012 described by Mirab-balou et al. (2012b) albopilosus Uzel, 1895

+ alliorum (Priesner, 1895)

added by Mirab-balou et al. (2012b)

angusticeps Uzel, 1895

atratus Haliday, 1836

+ australis Bagnall, 1915

added by Minaei (2012b)

dubius Priesner, 1927

euphorbiae Knechtel, 1923

flavus Schrank, 1776

fraudulentus (Priesner, 1954)

fuscipennis Haliday, 1836

hawaiiensis (Morgan, 1913)

iranicus Yakhontov, 1951

major Uzel, 1895

mareoticus (Priesner, 1932)

meridionalis (Priesner, 1926)

minutissimus Linnaeus, 1758

nigropilosus Uzel, 1895

pelikani Schliephake, 1964

physapus Linnaeus, 1758

pillichi Priesner, 1924

pistaciae Yakhontov, 1951

simplex (Morison, 1930)

tabaci Lindeman, 1889

trehernei Priesner, 1927

verbasci (Priesner, 1920)

vuilleti (Bagnall, 1933)

vulgatissimus Haliday, 1836 


\section{Suborder Tubulifera- Family Phlaeothripidae}

Only a single family is recognized in this suborder, the Phlaeothripidae, with two subfamilies, Idolothripinae and Phlaeothripinae. Species of Phlaeothripidae are diverse in their biologies. Idolothripinae are all considered to feed on fungal spores (Mound and Palmer 1983). In the Phlaeothripinae, three "lineages" (Haplothrips, Liothrips and Phlaeothrips) have been recognized (Mound and Marullo 1996). The Haplothrips lineage is now well defined as the tribe Haplothripini (Mound and Minaei 2007, Minaei and Mound 2008). Members of this tribe are usually phytophagous, but some Haplothrips species are predators on other small arthropods, and one unusual Haplothripine species has been demonstrated to be a predator of the eggs of social wasps (Cavalleri et al. 2013). Members of the "Phlaeothrips lineage" are fungus feeders on fungal hyphae (Mound et al. 2013a). Species in the "Liothrips lineage" are leaf-feeding on the leaves of shrubs and trees, and many of these are involved in the induction of galls on leaves (Ananthakrishnan and Raman 1989). Four species in four genera of Idolothripinae, and 41 species in 15 genera of Phlaeothripinae, are recognized in Iran.

\section{Subfamily Idolothripinae}

\section{Allothrips Hood, 1908}

+ pillichelus bournieri Mound, 1972 added by Minaei (2011)

\section{Compsothrips Reuter, 1901}

albosignatus (Reuter, 1884)

Megathrips Targioni-Tozzetti, 1881

flavipes (Reuter, 1901)

Pseudocryptothrips Priesner, 1919

meridionalis Priesner, 1919

\section{Subfamily Phlaeothripinae}

Tribe Haplothripini

\section{Bagnalliella Karny, 1920}

+ yuccae (Hinds, 1902)

added by Mirab-balou et al. (2012a)

Dolicholepta Priesner, 1932

micrura (Bagnall, 1914) 
Haplothrips Amyot \& Serville, 1843

aculeatus (Fabricius, 1803)

andresi Priesner, 1931

clarisetis Priesner, 1931

distinguendus (Uzel, 1895)

eragrostidis Priesner, 1931

flavicinctus (Karny, 1910)

flavitibia Williams, 1916

ganglbaueri Schmutz, 1913

globiceps (Bagnall, 1934)

+ herajius Minaei \& Aleosfoor, 2013 described by Minaei and Aleosfoor (2013)

kermanensis zur Strassen, 1975

kurdjumovi Karny, 1913

leucanthemi (Schrank, 1781)

maroccanus Priesner, 1950

phyllophilus Priesner, 1914

reuteri (Karny, 1907)

subtilissimus (Haliday, 1852)

tamaricinus Priesner, 1939

tritici (Kurdjumov, 1912)

vuilleti Priesner, 1920

Neobeegeria Schmutz, 1909

dalmatica Schmutz, 1909

gigantea (Priesner, 1934)

added by Minaei and Behmanesh (2012)

persica Priesner, 1954

Plicothrips Bhatti, 1979

apicalis (Bagnall, 1915)

\section{Liothrips lineage}

\section{Ataliothrips Bhatti, 1995}

reuteri (Bagnall, 1913)

\section{Cephalothrips Uzel, 1895}

coxalis Bagnall, 1926

monilicornis (Reuter, 1885)

\section{Liothrips Uzel, 1895}

austriacus (Karny, 1909)

jakhontovi Kreutzberg, 1955

pragensis Uzel, 1895

setinodis (Reuter, 1880) 


\section{Phlaeothrips lineage}

Aleurodothrips Franklin, 1909

+ fasciapennis Franklin, 1909

added by Mirab-balou and Chen (2012b)

Hindsiothrips Stannard, 1958

+ sisakhti Minaei, 2013

described by Minaei (2013b)

Hoplandrothrips Hood, 1912

bidens (Bagnall, 1910)

hungaricus Priesner, 1961

Hoplothrips Amyot \& Serville, 1843

+ An unknown species

added by Jalali Sandi et al. (2011)

Idiothrips Faure, 1933

+ bellus Faure, 1933

Idiothrips ficus Bhatti, 1967 is synonymized with bellus by Minaei (2013b)

Phlaeothrips Haliday, 1836

coriaceus Haliday, 1836

Stictothrips Hood, 1924

faurei Hood, 1924

\section{Unconfirmed Thysanoptera species}

\section{Aeolothripidae}

\section{Aeolothrips}

Cheraghian and Barimani Varandi (2000) reported A. insularis Priesner from Iran based on a specimen identified by zur Strassen as "near insularis" (e-mail from zur Strassen to Bhatti, see Bhatti et al. 2009a). Therefore, the record of Aeolothrips insularis in Iran is doubtful (see also Bhatti et al. 2009a). Moreover, the records of two other species in the genus, balati Pelikan and citricinctus Bagnall from Iran are also not confirmed (see Minaei 2013a). 


\section{Phlaeothripidae}

\section{Haplothrips}

The report of H. minutus (Uzel) from Iran is based on specimens identified by zur Strassen with a query (?). Similarly, the reports of three other species of Haplothrips, (caespitis Priesner, longipes Bagnall, and rabinovitchi Priesner) from Iran have also not been confirmed (Minaei and Mound 2008).

\section{Species removed from the Iranian Thysanoptera list}

\section{Thripidae}

Caliothrips striatopterus (Kobus, 1892): this species was recorded by Manzari (2004) in an informal newsletter as a cursory report, and so is excluded from the Iranian list (see also Bhatti et al. 2009a, Minaei and Aleosfoor 2013).

\section{Chaetanaphothrips Haliday, 1836}

The only mention of this genus in an Iranian context appeared in a text book (Esmaili 1983) with these thrips noted as potential pests in the north of Iran, but no species was recorded. The species in the genus are widespread in tropical and subtropical countries, and also in greenhouses in temperate areas including Europe (zur Strassen 2003); it is possible the genus may be found in Iran as well. However, at present there is no evidence to indicate the occurrence of any species of the genus in Iran.

\section{Frankliniella}

cephalica (Crawford DL, 1910): the species appeared in the Iranian literature as a potential pest in the north of Iran but with no recorded details of occurrence (Esmaili 1983). F. cephalica has been recorded between Bermuda and Trinidad, and in Mexico and Colombia as well as Japan and Taiwan (Hoddle et al. 2013).

sulphurea Schmutz, 1913: the species is considered as a good species by Bhatti et al. (2009a), but is usually considered a synonym of schultzei. The body colour in schultzei is variable and the species has 17 synonyms from various tropical countries around the world (Cavalleri and Mound 2012).

tritici (Fitch, 1855): the species appeared in the Iranian literature as an external plant quarantine element (but not recorded) (Salavatian 1996). F. tritici is widespread in North America (Hoddle et al. 2013). 
Scirtothrips citri (Moulton, 1909): the Californian citrus thrips was mentioned in the text book by Esmaili (1983) in which the author described damage to the flowers, leaves and fruits of citrus plants. However, no evidence was provided concerning the presence of this species in Iran. In addition to California, the species has been found in Arizona and Mexico (Hoddle et al. 2013).

Scolothrips sexmaculatus (Pergande, 1890): the species was first reported from Iran by Shishehbor (1991) based on specimens that were not authentically determined. The name was used subsequently by a few other Iranian authors. The species identified has been recorded with certainly only from North America (including California) (Hoddle et al. 2013). According to Mound (2011b), Old World records probably all refer to $S$. rhagebianus, which has been recorded in Iran (see also Bhatti et al. 2009a).

Thrips coloratus Schmutz, 1913: the species was recorded by Manzari (2004) in an informal newsletter as a cursory report and although potentially it might occur in Iran (zur Strassen 2003), it is excluded here.

\section{Phlaeothripdae}

\section{Haplothrips \\ bagnalli (Trybom, 1910) \\ nr. bagrolis Bhatti, 1973 \\ cerealis Priesner}

The first two species listed above have already been excluded from the Iranian list by Minaei and Aleosfoor (2013), whilst the third is a misidentification of Haplothrips tritici (Kurdjumov) (Minaei and Mound 2008). There is no evidence of the presence of cerealis in Iran (Minaei and Mound 2010b).

rasouliani Mirab-balou \& Chen: this name recently appeared in a paper (Mirabbalou et al. 2012c) but it is not available under the terms of the International Commission on Zoological Nomenclature International Commission on Zoological Nomenclature according to article 8.1, and so it is excluded here.

\section{Discussion}

Knowledge of the natural biological systems of Iran is variable. Despite excellent floristic studies, such as Flora Iranica that now provides an identification system to more than 10,000 plant species (Rechinger 1989), comprehensive studies on the insect fauna of this country are lacking. Iran, in particular, is a bridge between the faunas of the European and Oriental Realms, and this produces considerable difficulties in studying any single group. In addition, the number of species recorded from any given 
area in this country almost totally depends on where particular specialists have lived or spent their careers. Consequently, field sampling of the thrips fauna of Iran has been uneven across the various Provinces, and so the results do not necessarily represent the biological diversity of any given area. Although there are a few thrips (especially those that are well known as crop pests) that are found almost all over Iran, several Provinces have yet to be surveyed for their thrips fauna. Even in those Provinces that have been apparently well-surveyed, there are still thrips species remaining to be discovered. For instance, Fars Province has been surveyed for at least 14 years continuously yet there are still several examples of recently collected material from the Province in the Collection of Department of Plant Protection, Shiraz University, that represent unrecorded, or even undescribed species. Despite this, faunistic knowledge of these tiny insects in Iran is better than in neighbouring countries, presumably due to political unrest in most of the neighbouring countries.

Although the fauna of Iran shares many species with the European Mediterranean region, other areas have a considerable effect on the Iranian fauna. For example, among the 125 species from the family Thripidae recorded here, 91 are also present in the European Mediterranean area (zur Strassen 2003). Of the remaining species, 11 have been described from Iran and most of the other 23 species are from the Oriental.

\section{Acknowledgement}

I am grateful to Dom Collins (The Food and Environment Research Agency, Sand Hutton, York, United Kingdom) for reviewing an earlier draft of this manuscript as well as editorial help. The manuscript was improved through the advice and critics kindly provided by Laurence Mound (CSIRO Ecosystem Sciences, Canberra, Australia) and two anonymous referees.

\section{References}

Afshar DJ (1938) Pests of summer crops, vegetables, industrial plants and forages in Iran and their control. Ministry of Agriculture, Tehran, Iran, $124 \mathrm{pp}$.

Alavi J, Fekrat L, Modarres Awal M, Zolfaghari M, Minaei K (2013) Aeolothrips eremicola (Thysanoptera, Aeolothripidae): first record of the male from Iran. Zootaxa 3683: 289-291. http://biotaxa.org/Zootaxa/article/view/zootaxa.3683.3.5, doi: 10.11646/zootaxa.3683.3.5

Alavi J, Mosallaei MK, Sajjadi M (2012) First report of Aeolothrips wittmeri (Thysanoptera: Aeolothripidae) from Iran. Proceeding of the 20th Iranian Plant Protection Congress. Plant Diseases, Weed Science, Entomology, Acarology, Zoology, 195.

Ananthakrishnan TN, Raman A (1989) Thrips and gall dynamics. Oxford \& IBH Publ. Co. 120pp. Bagheri S, Alavi J (2007) New records of 20 species Thysanoptera on forest and rangeland plants for Iran and Khuzestan province. Proceedings of the 17th Iranian Plant Protection Congress, Tehran, Karaj, 78. 
Bhatti JS (1986) A new species of Holarthrothrips from Iraq, with notes on host plants and key to species, along with clarification of the position of this genus among Thysanoptera. Zoology (Journal of Pure and Applied Zoology) 1: 1-33.

Bhatti JS (1988) The orders Terebrantia and Tubulifera of the superorder Thysanoptera (Insecta). A Critical Appraisal. Zoology (Journal of Pure and Applied Zoology) 1: 167-240.

Bhatti JS (2006) The classification of Terebrantia (Insecta) into families. Oriental Insects 40: 339-375. doi: 10.1080/00305316.2006.10417487

Bhatti JS, Alavi J, zur Strassen R, Telmadarraiy Z (2009a) Thysanoptera in Iran 1938-2007. An Overview. Part 1. Thrips 7-8: 1-373.

Bhatti JS, Bagheri S, Ramezani L (2009b) A new species of Eremiothrips (Insecta: Terebrantia: Thripidae) from Khuzestan province in Iran. Thrips 10: 1-23.

Bhatti JS, Telmadarraiy Z, Kumar V, Tyagi K (2003) Species of Eremiothrips in Iran (Terebrantia: Thripidae). Thrips 2: 49-110.

Cavalleri A, Kaminski LA, Mendonca Jr MS (2010) Ectoparasitism in Aulacothrips (Thysanoptera: Heterothripidae) revisited: host diversity on honeydew-producing Hemiptera and description of a new species. Zoologischer Anzeiger 249: 89-101. doi: 10.1016/j. jcz.2010.09.002

Cavalleri A, Mound LA (2012) Toward the identification of Frankliniella species in Brazil (Thysanoptera, Thripidae). Zootaxa 3270: 1-30. http://www.mapress.com/zootaxa/2012/f/ zt03270p030.pdf

Cavalleri A, Souza AR, Prezotto F, Mound LA (2013) Egg predation within the nests of social wasps: a new genus and species of Phlaeothripidae, with consideration of the evolutionary consequences of Thysanoptera invasive behaviour. Biological Journal of the Linnean Society 109: 332-341. doi: 10.1111/bij.12057

Cheraghian A, Barimani Varandi H (2000) First record of three species of Thysanoptera in the north of Iran. Proceedings of the 14th Iranian Plant Protection Congress, Vol. 1: 297.

Esmaili M (1983) Important Pests of Fruit Trees. Sepehr Publishing, Tehran, 578 pp.

Fallahzadeh M, Azarmi E, Saghaei N, Alemansoor H, Alavi J (2011) Faunistic survey of Thysanoptera in Fars province, Iran. Munis Entomology \& Zoology 6: 251-261. http://www. munisentzool.org/yayin/vol6/issue1/251-261.pdf

Hoddle MS (2003) The effect of prey species and environmental complexity on the functional response of Franklinothrips orizabensis: a test of the fractal foraging model. Ecological Entomology 28: 309-318. doi: 10.1046/j.1365-2311.2003.00518.x

Hoddle MS, Mound LA, Paris D (2013) Thrips of California 2012. http://keys.lucidcentral. org/keys/v3/thrips_of_california/Thrips_of_California.html [accessed 5.vii.2013]

Jalali Sendi J, Zibaee I, Minaee K (2011) An Investigation on thrips fauna of Guilan province, north of Iran (Insecta: Thysanoptera). Munis Entomology \& Zoology 6: 325-329. http:// www.munisentzool.org/yayin/vol6/issue1/325-329.pdf

Kazemi F, Mehrnejad MR (2011) Population fluctuations and damage of the pistachio fruit thrips, Liothrips austriacus (Thy.: Phlaeothripidae) on Pistacia vera and Pistacia atlantica,subspecies P. mutica in Rafsanjan. Iranian Journal of Forest and Range Protection Research 8: 165-177. [in Persian] 
Kheyrandish Koshkoei M, Moharramipour S, Kamali K (2000) A report on Thysanoptera suborder Tubulifera in Kerman and records of three new species for Iran fauna. Proceedings of the 14th Iranian Plant Protection Congress, Vol. I, 354.

Manzari S (2004) Report of three species of thrips from Iranian islands in Persian Gulf. Newsletter of Entomological Society of Iran 21: 2. [in Persian]

Mehrnejad MR, Panahi B (2006) The influence of hull cracking on Aflatoxin contamination and insect infestation in pistachio nuts. Applied Entomology and Phytopathology 73: 105-123. [in Persian]

Minaei K (2011) Fungal spore-feeding thrips (Thysanoptera: Phlaeothripidae: Idolothripinae) from Iran with record of a fourth genus. Journal of Insect Science 11: 1-5. http://www. insectscience.org/11.51/i1536-2442-11-51.pdf, doi: 10.1673/031.011.5101

Minaei K (2012a) Ficothrips, a new genus of Thripinae Thysanoptera from Iran. Zootaxa 3361: 63-68.

Minaei K (2012b) First report of an endemic Australian thrips, Thrips australis (Thysanoptera: Thripidae) on Eucalyptus in Shiraz, Iran. Journal of Entomological and Acarological Research 44: 42-45. http://www.pagepressjournals.org/index.php/jear/article/view/ jear.2012.e9/pdf, doi: 10.4081/jear.2012.e9

Minaei K (2012c) The genus Eremiothrips (Thysanoptera: Thripidae) in Iran, with one new species. Zootaxa 3349: 56-62.

Minaei K (2013a) The genus Aeolothrips in Iran (Thysanoptera: Aeolothripidae) with one new species. Zootaxa 3630: 594-600. doi: 10.11646/zootaxa.3630.3.14

Minaei K (2013b) The Phlaeothrips-lineage of fungus feeding thrips in Iran with a new species of Hindsiothrips. Zootaxa 3599: 279-290. doi: 10.11646/zootaxa.3630.3.14

Minaei K, Aleosfoor M (2013) A new species of Haplothrips from southern Iran (Thysanoptera, Phlaeothripidae). ZooKeys 275: 91-99. doi: 10.3897/zookeys.275.4433

Minaei K, Alichi M (in press) The grass-living thrips (Insecta: Thysanoptera) from Iran with the first record of the genus Arorathrips Bhatti. Journal of Entomological and Acarological Research.

Minaei K, Behmanesh M (2012) First record of Neoheegeria gigantea (Thys.: Phlaeothripidae) from Iran. Journal of Entomological Society of Iran 32: 135-136.

Minaei K, Haftbaradaran F, Khosravi AR (2013) Occurrence of males among Aeolothripidae (Thysanoptera), with description of the male of Aeolothrips afghanus. Zootaxa 3681: 286288. doi: 10.11646/zootaxa.3681.3.8

Minaei K, Haftbaradaran F, Mound LA (2012) A new Ankothrips species (Thysanoptera: Melanthripidae) from Iran with unusually short setae. Zootaxa 3552: 37-42. http://www. mapress.com/zootaxa/2012/f/zt03552p042.pdf

Minaei K, Mound LA (2008) The Thysanoptera Haplothripini (Phlaeothripidae) of Iran. Journal of Natural History 42: 2617-2658. http://www.tandfonline.com/doi/ pdf/10.1080/00222930802354159, doi: 10.1080/00222930802354159

Minaei K, Mound LA (2010a) Grass-flower thrips of the genus Chirothrips (Thysanoptera: Thripidae), with a key to species from Iran. Zootaxa 2411: 33-43. http://www.mapress. com/zootaxa/2010/f/zt02411p043.pdf 
Minaei K, Mound LA (2010b) Taxonomic problems in character state interpretation: variation in the wheat thrips Haplothrips tritici (Kurdjumov) (Thysanoptera: Phlaeothripidae) in Iran. Deutsche Entomologische Zeitschrift 57: 233-241. doi: 10.1002/mmnd.201000020

Mirab-balou M, Chen XX (2010) First description of the male of the wheat thrips, Anaphothrips obscurus (Thysanoptera: Thripidae). Zootaxa 2540: 65-68.

Mirab-balou M, Chen XX (2011a) Iranian Thripinae with ctenidia laterally on the abdominal tergites (Thysanoptera: Thripidae). Natura Montenegrina 10: 435-466.

Mirab-balou M, Chen XX (2011b) The Megalurothrips genus-group in Iran (Thysanoptera: Thripidae). Munis Entomology \& Zoology 6: 944-952. http://www.munisentzool.org/ yayin/vol6/issue2/944-952.pdf

Mirab-balou M, Chen XX (2012a) A new species of Melanthrips from Iran (Thysanoptera: Melanthripidae) with a key to the Iranian species. Entomological News 122: 407-415. doi: $10.3157 / 021.122 .0502$

Mirab-balou M, Chen XX (2012b) Aleurodothrips fasciapennis Franklin: A newly recorded genus and species for Iran (Thysanoptera: Phlaeothripidae). Munis Entomology \& Zoology 7: 334-338. http://www.munisentzool.org/yayin/vol7/issue1/334-338.pdf

Mirab-balou M, Chen XX (2012c) Iranian thrips of the family Aeolothripidae with four newly recorded species. Vestnik Zoologie 46: 499-507.

Mirab-Balou M, Chen XX (2012d) The subfamily Panchaetothripinae (Thysanoptera: Thripidae) in Iran, with the first report of genus Selenothrips Karny. Entomotaxonomia 34: 22-29.

Mirab-Balou M, Chen XX (2013) New Records and Two New Species of the Anaphothrips Genus-Croup in Iran (Insecta: Thripidae). Acta Zoologica Bulgarica 65: 159-164

Mirab-Balou M, Minaei K, Chen XX (2013) An illustrated key to the genera of Thripinae (Thysanoptera, Thripidae) from Iran. Zookeys 317: 27-52. doi: 10.3897/zookeys.317.5447

Mirab-balou M, Shi M, Chen XX (2011) Two new species of the genus Mycterothrips from Western Iran (Thysanoptera: Thripidae). Zootaxa 3130: 57-62.

Mirab-balou M, Shi M, Chen XX (2012a) A newly recorded genus and species of Haplothripini (Thysanoptera: Phlaeothripidae) from Iran. Far Eastern Entomologist 240: 1-8.

Mirab-balou M, Tong XL, Chen XX (2012b) A new record and new species of the genus Thrips (Thysanoptera: Thripidae), with a key to species from Iran. Journal of Insect Sciences 12: 1-15. doi: 10.1673/031.012.9001

Mirab-balou M, Tong XL, Chen XX (2012c) Iranian Haplothrips with forewings sub-basal setae arranged in a triangle (Tubulifera: Phlaeothripidae). Persian Gulf Crop Protection 1: 15-21. http://cropprotection.ir/files_site/paperlist/Journal1-2-130726165154.pdf

Mortazaviha A (1995) Introduction of 15 species of thrips (Thysanoptera) collected in Iran. Proceedings of the 12th Iranian Plant Protection Congress, Junior College of Agriculture, Karaj, 341.

Mound LA (1997) Biological diversity. In: Lewis, T (Ed) Thrips as Crop Pests. CAB International, Wallingford, 197-215.

Mound LA (2002) Octothrips lygodii sp.n. (Thysanoptera, Thripidae) damaging weedy Lygodium ferns in southeastern Asia, with notes on other Thripidae reported from ferns. Australian Journal of Entomology 41: 216-220. doi: 10.1046/j.1440-6055.2002.00297.x 
Mound LA (2011a) Order Thysanoptera Haliday, 1836. In: Zhang Z-Q (Ed) Animal biodiversity: An outline of higher-level classification and survey of taxonomic richness. Zootaxa 201-202. http://www.mapress.com/zootaxa/2011/f/zt03148p202.pdf

Mound LA (2011b) Species recognition in the genus Scolothrips (Thysanoptera, Thripidae), predators of leaf-feeding mites. Zootaxa 2797: 45-53. http://www.mapress.com/ zootaxa/2011/f/zt02797p053.pdf

Mound LA, Dang LH, Tree DJ (2013a) Genera of fungivorous Phlaeothripinae (Thysanoptera) from dead branches and leaf-litter in Australia. Zootaxa 3681: 201-224. http://www. mapress.com/zootaxa/2013/f/zt03681p224.pdf, doi: 10.11646/zootaxa.3681.3.1

Mound LA, Marullo R (1996) The Thrips of Central and South America: An Introduction. Memoirs on Entomology, International 6: 1-488.

Mound LA, Marullo R (1999) Two new basal-clade Thysanoptera from California with Old World affinities. Journal of the New York entomological Society 106: 81-94.

Mound LA, Minaei K (2007) Australian thrips of the Haplothrips lineage (Insecta: Thysanoptera). Journal of Natural History 41: 2919-2978. doi: 10.1080/00222930701783219

Mound LA, Palmer JM (1983) The generic and tribal classification of spore-feeding Thysanoptera. Bulletin of the British Museum (Natural History) (Entomology) 46: 1-174.

Mound LA, Tree DJ (2009) Identification and host-plant associations of Australian Sericothripinae (Thysanoptera, Thripidae). Zootaxa 1983: 1-22. http://www.mapress.com/ zootaxa/2009/f/zt01983p022.pdf

Mound LA, Tree DJ, Paris D (2013b) OZ THRIPS, Thysanoptera in Australia. http://www. ozthrips.org/ [accessed 5.vii.2013]

Pereyra V, Mound LA (2009) Phylogenetic relationships within the genus Cranothrips (Thysanoptera, Melanthripidae) with consideration of host associations and disjunct distributions within the family. Systematic Entomology 34: 151-161. doi: 10.1111/j.13653113.2008.00445.x

Ramezani L, Bhatti JS, Mossadegh MS, Soleimannejadian E (2009) Discovery of Eremiothrips similis Bhatti 1988 in Iran (Insecta: Terebrantia: Thripidae). Thrips 11: 1-18.

Ramezani L, Mossadegh MS, Soleimannejadian E, Bagheri S, Minaei K (2011) The first report of the genus and species of Florithrips tragardhi (Thysanoptera: Thripidae) from Iran. Journal of Entomological Society of Iran 31: 101-103.

Rechinger KH (1989) Fifty years of botanical research in the Flora Iranica area (1937-1987). In: Tan K (Ed) The Davis and Hedge Festschrift: plant taxonomy, phytogeography and related subjects. Edinburgh, University Press, 301-349.

Salavatian M (1996) Plant Quarantine in Iran (Pests, Diseases and Weeds). Agricultural Research and Education Organization, Educational Technology Services Bureau, Agricultural Education Press, Karaj, 279 pp.

Shishehbor P (1991) Population dynamics of Tetranychus turkestani (U. \& N.) (Acari: Tetranychidae) on Castor bean in Southwestern Iran. Proceedings of the $10^{\text {th }}$ Plant Protection Congress of Iran, 88.

ThripsWiki (2013) ThripsWiki - providing information on the World's thrips. http://thrips. info/wiki/ [accessed 5.vii. 2013] 
Tyagi K, Kumar V, Mound LA (2008) Sexual dimorphism among Thysanoptera Terebrantia, with a new species from Malaysia and remarkable species from India in Aeolothripidae and Thripidae. Insect Systematics and Evolution 39: 155-170. doi: $10.1163 / 187631208788784093$

Wilson LJ, Bauer LR, Walter GH (1996) Phytophagous thrips are facultative predators of twospotted spider mites (Acari: Tetranychidae) on cotton in Australia. Bulletin of Entomological Research 86: 297-305. doi: 10.1017/S0007485300052597

Wilson TH (1975) A monograph of the subfamily Panchaetothripinae (Thysanoptera: Thripidae). Memoirs of the American Entomological Institute 23: 1-354.

Zehzad B, Kiabi BH, Madjnoonian H (2002) The natural areas and landscape of Iran: an overview. Zoology in the Middle East 26: 7-10. doi: 10.1080/09397140.2002.10637915

Zolfaghari M, Alavi J, Ravan S, Farsi-moghadam A (2012) Faunal study of Thysanoptera in the Sistan region of Iran. Proceeding of the $20^{\text {th }}$ Iranian Plant Protection Congress. Plant Diseases, Weed Science, Entomology, Acarology, Zoology, 137.

zur Strassen R (2003) Die terebranten Thysanopteren Europas und des Mittelmeer-Gebietes. Die Tierwelt Deutschlands 74: 1-271. [in German] 